\title{
Pengaruh Sosial Budaya Dan Geografis Terhadap Perilaku Merokok Lansia Perempuan Di Dataran Tinggi Dieng
}

\section{Socio-Cultural and Geographical Influences towards the Smoking Behavior of Elderly Women in Dieng Plateau}

\author{
Dwi Widiyaningsih $^{1}$, Dwi Suharyanta ${ }^{2}$ \\ ${ }^{12}$ Program Studi Ilmu Kesehatan Masyarakat STIKES Surya Global \\ widiya23juni@gmail.com \\ Jln Ringroad Selatan Blado Potorono Banguntapan Bantul Yogyakarta
}

\begin{abstract}
ABSTRAK
Kasus ISPA dari tahun 2009 sampai 2014 dan cenderung stagnant sampai tahun 2017, dan berbagai kejadian penyakit akibat rokok seperti TB paru, kanker dll juga banyak dijumpai di kabupaten Wonosobo. Penelitian ini bertujuan mencari pengaruh sosial budaya dan geografis terhadap perilaku merokok pada lansia perempuan di dataran tinggi Dieng. Subyek dari penelitian ini adalah lansia berjenis kelamin perempuan dengan usia diatas 60 tahun yang merokok. Populasi berjumlah 113 lansia, dengan teknik sampel total sampling.Jenis penelitian ini adalah kuantitatif dengan rancangan cross sectionaldan menggunakananalisis bivariat (kendall tau). Dan didapatkan hasil ada pengaruh yang signifikan antara sosial budaya terhadap perilaku merokok pada lansia perempuan $(0,001$ $<0,05$ ), ada pengaruh yang signifikan antara geografis terhadap perilaku merokok pada lansia perempuan $(0,000<0,05)$. Dengan tingkat signifikansi $0,000(\rho<0,05)$ Sehingga disimpulkan sosial budaya dan geografis ada kaitanya terhadap perilaku merokok perempuan didataran tinggi dieng.Adapun saran bagi peneliti selanjutnya adalah mencari peran keluarga dan peran tenaga kesehatan dalam pengendalian perokok pada lansia perempuan di dataran tinggi Dieng.
\end{abstract}

Kata kunci: Budaya, Sosial Geografis, Perilaku Merokok, Lansia Perempuan, Dieng Wonosobo

\section{ABSTRACT}

The case of URI (Upper Respiratory Tract Infection) experiences an increase from 2009 to 2014, while tends to be stagnant until 2017. In Wonosobo district, various cases of smoking-related diseases, such as pulmonary tuberculosis, cancer etc., are also discovered often. This research aims to realize the socio-cultural and geographical influences towards the smoking behavior of elderly women in Dieng Plateau. The subject of this research are the smoking elderly women with an age above 60 years. The population is about 113 elderly women selected through a total sampling technique. This research is a quantitative type of research with cross sectional design and applies bivariate analysis (Kendall tau). From the research results, it is realized that there is a significant influence of socio-cultural aspect towards the smoking behavior of the elderly women $(0.001<0.05)$. It also works for the geographical aspect $(0.000<0.05)$. With a significance level of $0.000(\rho<0.05)$, it can be concluded that socio-cultural and geographical aspects are related to the elderly women's smoking behavior in Dieng 
Dwi Widiyaningsih, Dwi Suharyanta: Socio-Cultural and Geographical Influences ....

Plateau. The suggestion for further researches is to find the role of family and health workers in controlling the smoking behavior of the elderly women in Dieng Plateau.

Keyword: culture, social geographic, smoking behavior, elderly women, Dieng Wonosobo

\section{PENDAHULUAN}

Indonesia adalah negara kepulauan yang kaya akan keanekaragaman sosial budaya dan geografis, masing-masing daerah memiliki keunikan tersendiri, dibalik keberagaman yang dimiliki tersimpan problematika kesehatan yang tersebar ke penjuru negeri, hal ini sangat membutuhkan perhatian karena tidak jarang ditemukan budaya dan kultur daerah yang tidak searah dengan pembangunan di bidang kesehatan, sebagai contoh di kawasan dataran tinggi dieng jawa tengah ada satu budaya merokok di kalangan lansia dan uniknya adalah berjenis kelamin perempuan, hal ini mencerminkan kekuatan dari wanita dieng dan kebersamaan saat merokok, jika budaya ini dilestarikan tentu dampak dari sisi kesehatan sangat merugikan apalagi dijadikan ikon destinasi wisata Dieng.

Sementara itu Apriana (2012) melaporkan bahwa jumlah perokok di dunia 41,6\%(Mathur et al., 2014).Menurut Laporan Southeast Asia Tobacco Control Alliance (SEATCA) berjudul The Tobacco Control Atlas(Lian \& Dorotheo, 2019), Asean Region menunjukkan Indonesia merupakan negara dengan jumlah perokok terbanyak di Asean, yakni 65,19 juta orang. Angka tersebut setara 34\% dari total penduduk Indonesia pada 2016, Jawa Tengah 35,1\% Angka ini lebih rendah dari dunia tetapi lebih tinggi dari angka nasional (Kementerian Kesehatan RI Badan Penelitian dan Pengembangan, 2018). Bahkan kebijakan pajak tidak mampu untuk mengurangi konsumsi rokok di Jawa Tengah pada tahun 2013. Meskipun sudah ada pajak rokok namun konsumsi rokok tetap terus meningkat (Wandita, 2020). Budaya merokok pada lansia perempuan yang juga dijadikan salah satu cara untuk menarik wisata juga dampaknya akan sangat berbahaya bagi paradigma masyarakat terkait perilaku merokok, belum lagi nasib generasi setelahnya yang ditakutkan akan mengikuti perilaku merokok para ibu atau nenek mereka.

World Health Organisation melaporkan bahwa penyebab kematian lebih dari 5 juta per tahun dan diperkirakan 10 juta tahun 2020, 70\% diantaranya berada dari negara berkembang disebabkan oleh penyakit akibat terpapar asap rokok (WHO, 2019). Kebiasaan merokok yang terus dilanjutkan ketika memiliki tekanan darah tinggi akan sangat berbahaya dan memicu penyakit yang berkaitan dengan jantung dan darah terutama untuk kelompok lansia (Komalasari \& Helmi, 2011). 
Kelompok beresiko (at risk) adalah sekelompok orang yang memiliki peluang resiko terjadinya masalah kesehatan penyakit tertentu baik ada maupun tidak adanya faktor yang berkonstribusi. Association of state and Territorial Health Offices mendefinisikan at risk berhubungan dengan faktor-faktor yang meningkatkan seseorang memperoleh suatu penyakit. Berdasarkan hal tersebut, maka kelompok resiko tinggi adalah kelompok yang memiliki peluang terjadinya sakit akibat factor resiko yang menyertai (Army, 2013).

Masa lansia adalah fase akhir kehidupan seseorang, di masa ini lansia akan mengalami kemunduran fisik, mental dan sosial secara bertahap, berbagai resiko peyakit akibat gaya hidup yang tidak baik juga akan perlahan mulai tampak, didukung dengan perilaku merokok pada kalangan lanjut usia dengan jenis kelamin perempuan tentunya menjadi fenomena yang tidak biasa kita jumpai, seperti di wilayah Dieng JawaTengah terdapat 4 dari 6 lansia perempuan yang memilki kebiasaan merokok di usia lansia di dukung dengan letak geografis yang berada kira-kira 2000 mdpl dengan suhu yang sangat dingin. Sehingga peneliti sangat tertarik untuk mengetahui pengaruh sosial budaya dan geografis terhadap perilaku merokok pada lansia perempuan di wilayah Dieng.

\section{METODE}

Jenispenelitian yang digunakan adalah deskriptif kuantitatif, yang dilaksanakan di Desa Dieng wetan kecamatan Kejajar kabupaten Wonosobo pada bulan Juni sampai September 2019 dengan jumlah sampel seluruh populasi yaitu 113, karena pengambilan sampel menggunakan tehnik total sampling. Tehnik pengumpulan data menggunakan instrument penelitian berupa Quesioner dengan pendekatan cross sectional dan analisa data menggunakan uji kendall's tau dengan program SPSS.16.

\section{HASIL}

Analisis Hasil Univariat

Tabel 1. Karakteristik Responden berdasar Kelompok Usia

\begin{tabular}{|c|c|c|c|c|c|}
\hline & & Frequency & Percent & $\begin{array}{c}\text { Valid } \\
\text { Percent }\end{array}$ & $\begin{array}{c}\text { Cumulative } \\
\text { Percent }\end{array}$ \\
\hline \multirow[t]{4}{*}{ Valid } & 60-69 tahun & 32 & 28.3 & 28.3 & 28.3 \\
\hline & 70-79 tahun & 46 & 40.8 & 40.8 & 69.1 \\
\hline & $>80$ tahun & 35 & 30.9 & 30.9 & 100.0 \\
\hline & Total & 113 & 100.0 & 100.0 & \\
\hline
\end{tabular}


Dwi Widiyaningsih, Dwi Suharyanta: Socio-Cultural and Geographical Influences ....

Dari data diatas sebaran karakteristik responden berdasarkan usia lansia yaitu usia 60-69 tahun berjumlah 32 orang atau 28,3 \%, lansia yang berusia 70-79 tahun berjumlah 46 orang atau 40,8\%, lansia berusia 80 tahun ke atas berjumlah 35 atau 30,9\%.Dari data tersebut dapat dilihat hampir separuh lebih lansia memiliki kelompok usia 70-79 tahun.

Tabel 2. Karakteristik Responden berdasarkan Jenjang Pendidikan

\begin{tabular}{lcccc}
\hline & Frequency & Percent & $\begin{array}{c}\text { Valid } \\
\text { Percent }\end{array}$ & $\begin{array}{c}\text { Cumulative } \\
\text { Percent }\end{array}$ \\
\hline Valid Tidak Sekolah & 35 & 31.0 & 31.0 & 31.0 \\
SD & 76 & 67,3 & 67,3 & 98,3 \\
SLTP & 2 & 1,7 & 1,7 & 100.0 \\
SLTA & 0 & 0 & 0 & 100.0 \\
Perguruan Tinggi & 0 & 0 & 0 & 100.0 \\
Total & 113 & 100.0 & 100.0 & \\
\hline
\end{tabular}

Data diatas sebaran karakteristik responden berdasarkan jenjang pendidikan yaitu lansia yang tidak bersekolah berjumlah 35 orang atau 31,0\%, lansia yang berpendidikan SD berjumlah 76 orang atau 67,3\%, lansia yang berpendidikan SLTP berjumlah 2 orang atau $1,7 \%$.

Tabel 3.Karakteristik Responden berdasar Jenis Pekerjaan

\begin{tabular}{llcccc}
\hline & & Frequency & Percent & $\begin{array}{c}\text { Valid } \\
\text { Percent }\end{array}$ & $\begin{array}{c}\text { Cumulative } \\
\text { Percent }\end{array}$ \\
\hline Valid & Ibu Rumah Tangga & 8 & 7.1 & 7.1 & 7.1 \\
& Pensiunan & 0 & 0.0 & 0.0 & 7.1 \\
& Buruh & 19 & 16.8 & 16.8 & 23.9 \\
Petani & 25 & 22.1 & 22.1 & 46.0 \\
Pedagang & 33 & 29.2 & 29.2 & 75.2 \\
& Wiraswasta & 28 & 24.8 & 24.8 & 100.0 \\
& Total & 113 & 100.0 & 100.0 & \\
\hline
\end{tabular}

Dari data diatas sebaran karakteristik responden berdasarkan pekerjaan yaitu lansia yang bekerja sebagai ibu rumah tangga sebanyak 8 orang atau 7,1\%, lansia yang 
bekerja sebagai buruh sebanyak 19 orang atau 16,8\%, lansia yang bekerja sebagai petani sebanyak 25 orang atau 22,1\%, lansia yang bekerja sebagai pedagang sebanyak 33 orang atau 29,2\%, dan lansia yang bekerja sebagai wiraswasta sebanyak 28 orang atau $24,8 \%$.

Tabel 4. Hasil Uji Kendall's Tau

\begin{tabular}{cccc}
\hline No & Variabel & Correlation Coefisient & Signifikan \\
\hline 1 & Sosial budaya & 0,277 & $0,001^{* *}$ \\
\hline 2 & Geografis & 0,541 & $0,000^{* *}$ \\
\hline
\end{tabular}

Dari tabel 4 diatas mengenai hasil uji kendall's tau pengaruh antara setiap variabel bebas dengan variabel terikatnya di ketahui bahwa ada pengaruh yang signifikan antara Sosial budaya dengandengan perilaku merokok pada lansia perempuanHal ini dilihat dari nilai signifikannya (p) $<0,05$ atau 0,001 < 0,05 yang berarti Ho ditolak dan Ha diterima yaitu ada korelasi antara Sosial budaya dengandengan perilaku merokok pada lansia perempuan. Dan hasil uji (r hitung) sebesar 0,277 yang berada pada interval 0,260,50 yang menandakan tingkat korelasinya sedang.

Dapat diketahui juga bahwa ada pengaruh yang signifikan antara Geografis dengandengan perilaku merokok pada lansia perempuan Hal ini dilihat dari nilai signifikannya (p) $<0,05$ atau 0,000 < 0,05 yang berarti Ho ditolak dan Ha diterima yaitu ada korelasi antara Geografis dengandengan perilaku merokok pada lansia perempuan. Dan hasil uji (r hitung) sebesar 0,541 yang berada pada interval 0,51 s/d 0.75 yang menandakan tingkat korelasinya artinya hubungan kuat.

\section{PEMBAHASAN}

Indonesia selalu menaruh kisah dan sejarah yang menarik untuk dikunjungi dan dipelajari, dan salah satu yang menjadi pesona negera ini adalah keanekaragaman sosial dan budaya yang sudah kian menggema diseluruh penjuru dunia, budaya ramah tamah dan empati yang tinggi merupakan bukti nyata bahwa kebudayaan membawa rakyat Indonesia dikenal dengan budi luhur dan keramah-tamahan. Akan tetapi terkadang kehidupan sosial budaya diiringi dengan perilaku yang sebaliknya dengan dalih saling menghormati kebiasaan dan budaya suatu kelompok masyarakat, misalkan budaya merokok pada lansia perempuan yang secara turun menurun masih menjadi fenomena unik didaerah dataran tinggi dieng. Hal ini seiring dengan penelitian yang menyebutkan perilaku merokok dipengaruhi tiga faktor utama: faktor sosial, psikologi, dan lingkungan.

Hasil penelitian ini memperlihatkan bagaimana sosial budaya akan membawa dampak keikutsertaan dalam masyarakat dan kebiasaan yang sudah ditetapkan di suatu 
daerah atau wilayah sebagai bentuk menjunjung budaya dalam rangka meningkatkan hubungan sosial masyarakat mencapai 58\%.Sebagaimana diuraikan oleh Iman Budhi Santosa (Budhi Santosa, 2012), peran rokok dalam kehidupan sosial masyarakat Jawa tidak dapat dihilangkan begitu saja melalui penerbitan UU atau PP bahkan fatwa MUI sekalipun, menurutnya menghisap rokok kretek bagi orang Jawa terutama kalangan rakyat jelata telah menjadi bagian dari kebudayaan bukan hanya soal kebiasaan, menurutnya lagi merokok bagi sebagian orang jawa adalah salah satu cara untuk melepaskan beban hati dan penat pikiran, dengan kata lain me-time nya adalah dengan merokok.

Perilaku merokok bagi lansia di daerah ini juga sangat terpengaruh dengangeografis, alam terjal dan suhu yang dingin tentu menjadi salah satu penghalang dalam orang berkreatifitas, dan sebagain dari mereka menghalaunya dengan merokok, hal ini juga diceritakan oleh (Budhi Santosa, 2012) bahwa rokok sering dikaitkan dengan kreativitas, banyak penyair, sastrawan dan novelis Indonesia yang tidak lepas dari rokoknya sebagai salah satu contoh adalah Chairil Anwar. Menurutnya nikotin dalam rokok mampu membuat otak rileks dan dapat memunculkan ide cemerlangnya, bahkan ada salah seorang teman penulis buku tersebut membeberkan salah satu temanya hanya akan nyambung saat ngobrol ketika merokok.Dari uraian tersebut kita akan menyimpulkan bahwa cara pandang orang terhadap rokok dan perilaku merokok dalam masyarakat ternyata sangat kompleks dan saling bertolak belakang. Namun bagaimanapun perilaku merokok tentu menjadi hal yang tidak terlalu baik terlebih dilakukan tanpa etika, karena pada zaman sekarang ini yang lebih utama adalah etika merokok (Budhi Santosa, 2012).

Kelompok usia lansia pada penelitian ini di dominasi oleh usia 70-79 tahun sebesar 40,8 \% di susul usia 60-69 tahun sebesar 28,3\% dimana sampai penelitian selesai dilakukan mereka masih menjadi perokok aktif yang bisa menghabiskan rata-rata 5 batang setiap harinya hal ini senada dengan penelitian perilaku lansia dalam kehidupan berkelompok akan terpengaruh dengan lingkungan yang membersamainya (Ada 3 faktor yang saling menunjang untuk pembentukan sikap, yaitu kognitif, konatif, dan afektif yang merupakan presdiposisi terhadap tindakan dan perilaku seseorang (Sigalingging dalam Novianti, 2018).

Jika menilik dari segi pedidikan, sejumlah 113 reponden dalam penelitian ini tidak ada yang memiliki pendidikan SMA atau sederajat apalagi pendidikan tinggi, tingkat pendidikan 67,3\% adalah tamatan Sekolah Dasar atau SR dan 31\% bahkan tidak 
tamat SD atau kita kategorikan tidak bersekolah. Sehingga kita sepakat dengan teori L.Green bahwa tingkat pendidikan mempengaruhi perilaku seseorang(Notoatmodjo, 2014). Belum lagi yang disampaikan Budhi Santosa, 2012, sebagian orang jawa adalah rakat jelata yang menjadikan rokok sebagai alat pelrian untuk tetap melanjutkan hidup dan kewarasan dalam menghadapi kerasnya kehidupan.

Tentu hal ini ada dua sisi yang saling bertolak belakang, sisi pertama adalah menghormati kebudayaan nenek moyang namun disisi lain praktek perilaku tidak sehat yang mereka tidak sadari justru akan memberikan dampak negatif terhadap lingkungan, sebagaimana dalam sebuah kajian mengenai Faktor yang memengaruhi perilaku merokok wanita dewasa adalah keinginan untuk diterima dan menjadi bagian dari kelompok teman sebaya, orangtua perokok (khususnya ibu), keinginan kuat untuk mencoba rokok, iklan rokok, dan tidak percaya rokok berbahaya untuk kesehatan(Brahmana, 2009). Pengaruh bahan-bahan kimia yang dikandung rokok seperti nikotin, CO (Karbonmonoksida) dan tar akan memacu kerja dari susunan syaraf pusat dan susunan syaraf simpatis sehingga mengakibatkan tekanan darah meningkat dan detak jantung bertambah cepat.

Letak Geografis dataran tinggi dieng memberikan tantangan tersendiri bagi penghuninya, suhu yang dingin bahkan cenderung extrim untuk wilayah tropis membuat warga melakukan berbagai kegiatan fisik maupun non fisik untuk menghangatkan tubuh mereka, sayangnya fakta yang ada sangat mencengangkan mayoritas penduduk di desa dieng pernah merokok baik dari kalangan remaja, dewasa bahkan lansia dan yang lebih mengejutkan adalah fenomena perokok lansia perempuan yang dijadikan budaya tersendiri bagi kaum wanita pesohor.

Tidak banyak diketahui oleh khalayak bahwa status sosial diwilayah Dieng biasanya dilihat dari merk rokok yang dihisap oleh lansia perempuan di suatu rumah. Disisi lain Analisis kompleks wilayah membandingkan berbagai kawasan di muka bumi dengan memperhatikan aspek-aspek keruangan, dan lingkungan dari masing-masing wilayah secara komprehensif. Contohnya, wilayah kutub tentu sangat berbeda karakteristik wilayahnya dengan wilayah khatulistiwa (Army, 2013).Perbedaan karakteristik masyarakat yang tinggal di berbagai perbedaan geografis inilah yang membedakan perilaku mereka secara keseharian.

Angka kematian akibat penyakit yang disebabkan oleh rokok di Indonesia semakin meningkat bahkan prevalensi perokok Indonesia tidak pernah mengalami penurunan sejak tahun 1980-2013(Drope, Schluger, Cahn, Drope, Hamill, Islami, Liber, Nargis, 2018). Terdapat sekitar 5,8 triliun perokok di seluruh dunia, 176 juta diantaranya 
adalah wanita jumlah perokok wanita semakin meningkat khususnya pada usia remaja(Wipfli, 2012). Hal ini dipicu karena kecenderungan meniru kepada orang sekitarnya terutama seorang ibu dalamsebuahpenelitian ditemukan enam hal utama terkait perilaku merokok pada wanita yaitu : 1) awal mula perilaku merokok pada wanita; 2) proses perilaku merokok wanita; 3) pengetahuan dampak merokok pada wanita; 4) pandangan terhadap nilai-nilai perilaku merokok wanita; 5) ketersediaan informasi mengenai dampak rokok dari tenaga kesehatan; dan 6) pengaruh panutan.

Di wilayah dieng perilaku merokok pada lansia merupakan pemandangan yang biasa dan sudah menjadi lumrah bahkan mereka akan bebas dan leluasa merokok didalam rumah yang notabene didalamnya terdapat anak balita sehingga dijumpai banyak sekali kejadian ISPA di daerah ini(Kabupaten \& Dinas Kesehatan, 2017). Belum lagi alibi bahwa meskipun merokok mereka sehat senada dengan pernyataan sebuah penelitian bahwa Pengalaman dampak merokok. Sebagian perokok wanita merasa sehat dan tidak merasakan dampak merokok. Hal ini disebut sebagai risk-exempting belief,yaitu keyakinan bebas risiko dari merokok yang dilakukan(Scarinci et al., 2007).

Kebiasaan yang dilakukan lansia perempuan di dataran tinggi dieng ini dilakukan setelah mereka melakukan aktivitas fisik dalam pekerjaan mereka,seperti naik gunung untuk mencari kayu bakar, ke kebun kentang atau setelah menikmati hidangan maka mereka akan segera merokok, menurut mereka kenikmatan perokok wanita adalah merokok setelah makan, bila tidak merokok setelah makan justru terasa pahit. Padahal ini adalah bentuk kebiasaan yang berubah menjadi candu akibat kandungan nikotin rokok(Karini \& Padmawati, 2018).

Kondisi berkumpul dengan komunitas lansia atau warga yang merokok juga akan membuat lansia semakin banyak dalam menghisap rokok hal ini sebagaimana diceritakan oleh salah seorang responden yang kami wawancarai. Saat merokok bersama dengan teman-teman seseorang cenderung merokok lebih banyak(Otsuki, 2009). Hal ini juga senada dengan peneltian Lanjut usia yang dapat terus menjalin interaksi sosial dengan baik adalah lansia yang dapat mempertahankan status sosialnya berdasarkan kemampuan bersosialisasi (Noorkasiani dalam Andesty et al., 2018).

Perokok wanita merasa di satu pihak pemerintah melarang untuk merokok, namun kenyataan di kehidupan sehari-hari perokok wanita masih menemukan rokok dijual bebas dan mendapati rokok merk baru bermunculan dengan harga lebih murah yang tentunya hal ini berbanding terbalik dengan yang dikemukakan oleh Desliyani Tri Wandita 2020, terkait kenaikan cukaitelah dirilis oleh kemenkeu, namun perilaku 
merokok lansia tidak juga menurun. Sementara menurut Aditama (dalam Wandita, 2020), kebiasan merokok telah terbukti berhubungan dengan 25 jenis penyakit dari berbagai alat tubuh manusia, seperti kanker paru, bronkitis kronik, emfisema dan berbagai penyakit paru lainnya namun lansia perempuan tetap tidak bergeming untuk mengurangi perlaku merokoknya.

. Indonesia adalah salah satu negara Islam, seharusnya membuat kebijakan yang tegas terhadap rokok karena telah diharamkan dalam Agama Islam, namun karena industri rokok merupakan penyerap kedua terbesar untuk tenaga kerja, hal ini membuat Indonesia tidak bisa menghentikan produksi rokok(Ghouri et al., 2006).

Menurut Sari (Wandita, 2020) juga menyebutkan bahwa tidak ada pengaruh pajak rokok terhadap konsumsi rokok di Jawa Tengah pada tahun 2013. Mantan perokok akan kembali merokok bila berada di lingkungan sekitar orang-orang yang merokok(Orton et al., 2016). Pengambilan keputusan tersebut didasari oleh sebuah kesadaran, yang berawal dari niat (intensi) sehingga terbentuk suatu perilaku. Pemilihan menggunakan Theory of Planned Behavior(Mindianata, 2018).

\section{SIMPULAN}

Budaya merokok dari zaman nenek moyang sangat melekat pada masyarakat Dieng sebagai simbol kelestarian budaya namun tidak mengedepankan asas kesehatan, paradigma tersebut turun temurun sehingga perilaku merokok pada perempuan terus berlanjut hingga kini meskipun tingkat korelasi sosial budaya dengan perilaku merokok pada penelitian ini sedang dengan angka 0,277 dan nilai signifikansi 0,001 $<0,05$, sedangkan geografis mempunyai pengaruh yang signifikan terhadap perilaku merokok lansia perempuan dengan $(\mathrm{p})<0,05$ atau 0,000 $<0,05$ dengan korelasi kuat sebesar sebesar 0,541 .

\section{UCAPAN TERIMA KASIH}

Ucapan terimakasih yang sebesar-besarnya kami sampaikan kepada 1)Direktorat Riset dan Pengabdian Masyarakat Direktorat Jenderal Penguatan Riset dan Pengembangan Kementerian Riset, Teknologi dan Pendidikan Tinggi, 2)LLDIKTI Wilayah V, 3)Kecamatan Kejajar, 4)STIKES Surya Global Yogyakarta. 
Dwi Widiyaningsih, Dwi Suharyanta: Socio-Cultural and Geographical Influences ....

\section{DAFTAR PUSTAKA}

Andesty, D., Syahrul, F., Epidemiologi, D., Masyarakat, F. K., \& Airlangga, U. (2018). Hubungan Interaksi Sosial Dengan Kualitas Hidup Lansia Di Unit Pelayanan Terpadu (UPTD) Griya Werdha Kota Surabaya Tahun 2017 Pendahuluan Dampak Dari Kemajuan Ilmu Pengetahuan Dan Teknologi Terutama Di Bidang Kesehatan , Berhasil Untuk Menurunkan Angka. The Indonesian Journal of Public Health,13(December), 169-180. https://doi.org/10.20473/ijph.vl13il.2018.169-180

Army, A. P. (2013). Wikipedia bahasa Indonesia, ensiklopedia bebas (p. 3). http://id.wikipedia.org/wiki/Riset

Brahmana, K. M. B. (2009). Gambaran Faktor-Faktor Yang Mempengaruhi Wanita Dewasa Muda Dalam Mengambil Keputusan Mengkonsumsi Rokok (Jenis Lights Atau Non Lights). VISI, 17(1), 90-107.

Budhi Santosa, I. (2012). Ngudud: Cara Orang Jawa Menikmati Hidup. Manasuka.

Drope, Schluger, Cahn, Drope, Hamill, Islami, Liber, Nargis, S. (2018). The Tobacco Atlas. Atlanta: American Cancer Society and Vital Strategies. In Word Lung. www.tobaccoatlas.org

Ghouri, N., Atcha, M., \& Sheikh, A. (2006). Influence of Islam on smoking among Muslims. British Medical Journal, 332(7536), 291-294. https://doi.org/10.1136/bmj.332.7536.291

Kabupaten, P., \& Dinas Kesehatan, W. (2017). "Bersatu Mewujudkan Wonosobo Sehat” 2017 (Issue 02).

Karini, T. A., \& Padmawati, R. S. (2018). Fenomena sosial unik pada perokok wanita di kabupaten Lebong Bengkulu Indonesia. Berita Kedokteran Masyarakat, 34(1), 1924. https://media.neliti.com/media/publications/237887-none-034f3c75.pdf

Kementerian Kesehatan RI Badan Penelitian dan Pengembangan. (2018). Hasil Utama Riset Kesehatan Dasar. Kementrian Kesehatan Republik Indonesia, 1-100. http://www.depkes.go.id/resources/download/info-terkini/hasil-riskesdas-2018.pdf

Komalasari, D., \& Helmi, A. F. (2011). Faktor Faktor Penyebab Merokok Pada Remaja. Jurnal Psikologi, 27(1), 37-47.

Lian, T., \& Dorotheo, U. (2019). The Tobacco Control Atlas: ASEAN Region, Fourth Edition. In Clove Cigarettes May Prompt U.S., Indonesia Dispute (Issue September). https://seatca.org/clove-cigarettes-may-prompt-u-s-indonesia-dispute/

Mathur, C., Stigler, M. H., Erickson, D. J., Perry, C. L., \& Forster, J. L. (2014). Transitions in smoking behavior during emerging adulthood: A longitudinal analysis of the effect of home smoking bans. American Journal of Public Health, 104(4), 715-720. https://doi.org/10.2105/AJPH.2013.301642

Mindianata, P. (2018). Faktor-Faktor Yang Berpengaruh Terhadap Niat Keaktifan Lansia Dalam Mengikuti Posyandu Lansia. Jurnal PROMKES, 6(2), 213. https://doi.org/10.20473/jpk.v6.i2.2018.213-226

Notoatmodjo, S. (2014). ILMU PERILAKU KESEHATAN (p. 173). Rineka Cipta.

Novianti. (2018). Faktor-faktor yang mempengaruhi perilaku lansia dala mengikuti senam lansia. Jurnal Keperawatan Silampari, 1(2), 123-138. https://doi.org/https://doi.org/10.31539/jks.v1i2.84

Orton, S., Coleman, T., Lewis, S., Cooper, S., \& Jones, L. L. (2016). "I was a full time proper smoker": A qualitative exploration of smoking in the home after childbirth among women who relapse postpartum. PLoS ONE, 11(6), 1-16. https://doi.org/10.1371/journal.pone.0157525

Otsuki, M. (2009). Social connectedness and smoking behaviors among Asian American college students: An electronic diary study. Nicotine \& Tobacco Research, 11(4), 418-426. https://doi.org/10.1093/ntr/ntp028 
Scarinci, I. C., Silveira, A. F., Dos Santos, D. F., \& Beech, B. M. (2007). Sociocultural factors associated with cigarette smoking among women in Brazilian worksites: A qualitative study. Health Promotion International, 22(2), 146-154. https://doi.org/10.1093/heapro/dam012

Wandita, D. T. (2020). Pengaruh Cukai Rokok Terhadap Konsumsi Rokok Serta Faktorfaktor Yang Mempengaruhi Konsumsi Rokok. Jurnal Pendidikan Ekonomi, 14(1), 159-165. https://doi.org/10.19184/jpe.v14i1.16659

WHO. (2019). Tubuh tembakau. 1. WHO/NMH/PND/19.1

Wipfli, H. (2012). The Tobacco Atlas, Fourth Edition. American Journal of Epidemiology, 176(12), 1193-1193. https://doi.org/10.1093/aje/kws389

\begin{tabular}{|l|r|}
\hline Submission & 09 Sepember 2020 \\
\hline Review & 23 September 2020 \\
\hline Accepted & 29 September 2020 \\
\hline Publish & 26 Oktober 2020 \\
\hline DOI & https://sinta.ristekbrin.go.id/journals/detail?id=3576 \\
\hline Sinta Level & . \\
\hline
\end{tabular}

